\title{
IMPLEMENTASI KEBIJAKAN PENGELOLAAN LIMBAH RUMAH SAKIT DI RUMAH SAKIT ISLAM SULTAN AGUNG KOTA SEMARANG
}

\author{
Siti Chotijah, Dewi Tuti Muryati, Tri Mulyani \\ Fakultas Hukum Universitas Semarang \\ schotijah99@gmail.com,dewi_tuti@yahoo.com,trimulyani@gmail.com
}

\begin{abstract}
ABSTRAK
Rumah Sakit Islam Sultan Agung Kota Semarang merupakan salah satu institusi pelayanan kesehatan profesional. Aktifitas medis yang ada di Rumah Sakit Islam Sultan Agung tentunya akan menghasilkan limbah, sehingga peneliti tertarik untuk mengkaji tentang sejauh mana Rumah Sakit Islam Sultan Agung mengimplementasi kebijakan pengelolaan limbah Rumah Sakit serta mengetahui kendala yang dihadapi dan cara mengatasinya. Peneliti menggunakan jenis penelitian yuridis sosiologis dengan spesifikasi yang digunakan yaitu deskriptif analitis, seperti mendeskripsikan mengenai implementasi kebijakan pengelolaan limbah di Rumah Sakit Sultan Agung berdasarkan Keputusan Menteri Kesehatan Republik Indonesia Nomor 1204/MENKES/SK/X/2004 tentang Persyaratan kesehatan lingkungan Rumah Sakit. Penelitian ini menggunakan cara pengambilan sampel sistematis Non Random yang dilakukan dengan cara teknik Purposive Sampling yang dilakukan dengan cara menentukan kriteria sampel terlebih dahulu. Data yang dipergunakan dalam penelitian ini adalah data primer, yang diperoleh melalui wawancara terhadap pihak terkait secara langsung serta didukung oleh data sekunder yang berupa studi keperpustakaan. Dari hasil penelitian, implementasi kebijakan pengelolaan limbah rumah sakit di Rumah Sakit Islam Sultan Agung Kota Semarang sudah berjalan dengan baik sesuai dengan Nomor 1204/MENKES/SK/X/2004 tentang Persyaratan Kesehatan Lingkungan Rumah Sakit. Adapun kendala yang ada mengenai standar baku mutu amonia akan tetapi kendala tersebut telah ditepuh upaya mengatasi kendala oleh Rumah Sakit Islam Sultan Agung berupa mengadakan pertemuan forum sanitasi sekota semarang dan mendapatkan hasil berupa kebijakan baru yaitu Peraturan Menteri Lingkungan Hidup Dan Kehutanan Republik Indonesia Nomor P.68/Menlhk/Setjen/Kum.1/8/2016 tentang Baku Mutu Air Limbah Domestik.
\end{abstract}

\section{Kata kunci : Kebijakan; Pengelolaan; Limbah Rumah Sakit;}

\begin{abstract}
ABSTRACK
Sultan Agung Hospital Semarang is one of the institutions of professional health services. Medical activity at Sultan Agung Islamic Hospital will surely produce waste, so the researcher is interested to study about the extent to which Sultan Agung Islamic Hospital implements the hospital waste management policy and knows the constraints faced and how to overcome them. The researcher uses a kind of sociological juridical research with the specification that is used that is analytical descriptive, such as describing the implementation of waste management policy at Sultan Agung Hospital based on the Decree of the Minister of Health of the Republic of Indonesia No. 1204 / MENKES / SK / X / 2004 on Hospital health requirements. This research uses non-random systematic sampling method done by Purposive Sampling technique which is done by determining the criteria of sample first. The data used in this study is primary data, obtained through interviews of stakeholders directly and supported by secondary data in the form of study keperpustakaan. From the research result, the implementation of hospital waste management policy at Sultan Agung Hospital Semarang City has been running well in accordance with Number 1204 / MENKES / SK / X / 2004 on Health Requirements for Hospital Environment. The obstacles that exist about the standard quality of ammonia but these obstacles have been plagued efforts to overcome obstacles by Sultan Agung Islamic Hospital in the form of meeting the city sanitation forum semarang and get results in the form
\end{abstract}


of a new policy of Minister of Environment and Forestry Regulation of the Republic of Indonesia Number P.68 /Menlhk/Setjen/Kum.1/8/2016 on the Quality Standards of Domestic Waste Water.

Keywords : Policy; Management; Waste; Hospital

\section{A. Pendahuluan}

Dewasa ini perkembangan teknologi sangat pesat. Dengan adanya perkembangan teknologi, memicu berkembangnya pula industri - industri baru di Indonesia khususnya di kota - kota besar seperti Kota Semarang. Hal ini akan memancing penduduk untuk melakukan urbanisasi ke Kota Semarang. Aktivitas seperti ini tentunya berpotensi mengancam kesehatan lingkungan. Masalah lingkungan erat sekali berhubungan dengan dunia kesehatan. Kesehatan merupakan hak asasi manusia yaitu setiap orang mempunyai hak yang sama dalam memperoleh akses pelayanan kesehatan. Diatur dalam Pasal 28H Amandemen ke - IV Undang - Undang Dasar Replubik Indonesia 1945. Sesuai dengan Pasal 162 UU Nomor 36 Tahun 2009 tentang Kesehatan menyatakan bahwa upaya kesehatan lingkungan ditujukan untuk mewujudkan kualitas lingkungan yang sehat, baik fisik, kimia, biologi, maupun sosial yang memungkinkan setiap orang mencapai derajat kesehatan yang setinggi - tingginya. Tetapi dengan adanya beberapa pelayanan kesehatan di Kota Semarang juga mengancam kesehatan lingkungan karena kegiatan pelayanan kesehatan akan menghasilkan limbah. Dalam hal penanganan dan pengelolaan limbah rumah sakit, diperlukan kesadaran lingkungan yang baik dari pengelola rumah sakit agar limbah yang hasilkan tidak mencemari alam sekitar. Menurut RTM Sutamiharja, pemcemaran adalah penambahan bermacam - macam bahan sebagai hasil dari akivitas manusia ke lingkungan dan biasanya memberikan pengaruh yang berbahaya terhadap lingkungan. ${ }^{1}$

Disebutkan dalam Pasal 4 UU Nomor 32 Tahun 2009 tentang Perlindungan dan Pengelolaan Lingkungan Hidup bahwa Perlindungan dan pengelolaan lingkungan hidup meliputi :
a. Perencanaan
b. Pemanfaatan
c. Pengendalian
d. Pemeliharaan
e. Pengawasan
f. Penegakan hukum

Berangkat dari sinilah peran pemerintah sebagai pengawas yang bertanggung jawab dalam mengawasi pembuangan, penanganan dan pengelolaan limbah yang dihasilkan sesuai dengan isi Pasal 163 ayat (1) UU Nomor 36 Tahun 2009 tentang Kesehatan. Pada Pasal 14 UU Nomor 32 Tahun 2009 tentang Perlindungan dan Pengelolaan Lingkungan Hidup terdapat pula instrumen

\footnotetext{
1 Muhammad Erwin, Hukum Lingkungan : Dalam Sistem Kebijaksanaan Pembangunan Lingkungan Hidup (Bandung:Refika Aditama, 2008), halaman 36.
} 
pencegahan pencemaran dan/atau kerusakan lingkungan hidup. Instrumen pencegahan pencemaran dan/atau kerusakan lingkungan hidup terdiri atas:

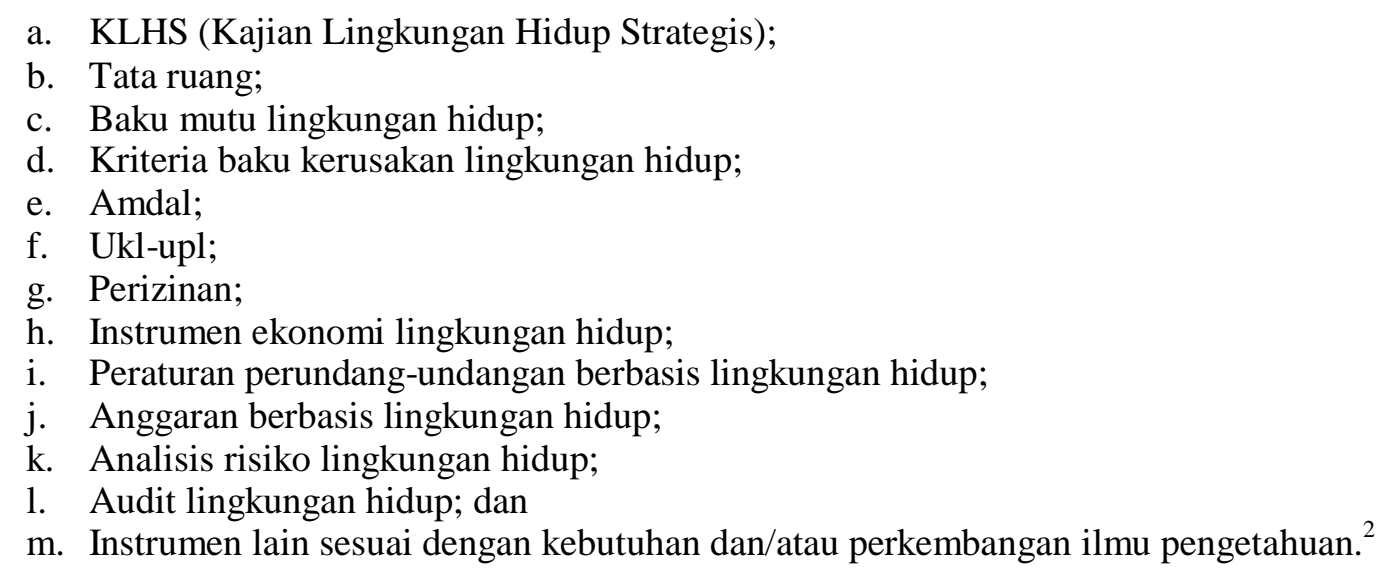

Pengawasan pemerintah berupa audit lingkungan hidup perlu guna mengevaluasi ketaatan pengelola rumah sakit terhadap implementasi kebijakan pemerintah yang berlaku untuk mencegah terjadinya pencemaran lingkungan hidup. Berdasarkan data dari Badan Pusat Statistik Kota Semarang di tahun 2015 terdapat 27 unit rumah sakit di daerah Semarang, baik rumah sakit negeri maupun swasta. Salah satu rumah sakit swasta yang berada di daerah padat penduduk di Kota Semarang yaitu Rumah Sakit Islam Sultan Agung. Keikutsertaan Rumah Sakit Islam Sultan Agung dalam kegiatan kesehatan lingkungan seperti pengelolaan limbah rumah sakit dengan baik dan benar sangatlah penting guna menciptakan lingkungan yang sehat dan terhindar dari pencemaran lingkungan. Berdasarkan latar belakang yang telah diuraikan, penulis tertarik untuk meneliti dengan judul "Implementasi Kebijakan Pengelolaan Limbah Rumah Sakit di Rumah Sakit Islam Sultan Agung Kota Semarang”.

\section{B. RUMUSAN MASALAH}

Berdasarkan uraian dari latar belakang, maka dapat dirumuskan permasalahan sebagai berikut:

1. Bagaimanakah implementasi kebijakan pengelolaan limbah rumah sakit di Rumah Sakit Islam Sultan Agung Kota Semarang?

2. Kendala apakah yang dihadapi oleh Rumah Sakit Islam Sultan Agung Kota Semarang dalam mengimplementasikan kebijakan pengelolaan limbah rumah sakit?

3. Bagaimana upaya mengatasi kendala yang dihadapi oleh Rumah Sakit Islam Sultan Agung Kota Semarang dalam mengimplementasikan kebijakan pengelolaan limbah rumah sakit? 


\section{Tujuan dan Manfaat Penelitian}

\section{Tujuan Penelitian}

a. Untuk mengetahui implementasi kebijakan pengelolaan pengelolaan limbah rumah sakit di Rumah Sakit Islam Sultan Agung Kota Semarang.

b. Untuk mengetahui kendala - kendala yang dihadapi oleh Rumah Sakit Islam Sultan Agung Kota Semarang dalam mengimplementasikan kebijakan pengelolaan limbah.

c. Untuk mengetahui upaya mengatasi kendala yang dilakukan Rumah Sakit Islam Sultan Agung Kota Semarang dalam mengimplementasikan kebijakan pengelolaan limbah

\section{Manfaat Penelitian}

\section{a. Manfaat Teoritis}

a) Penelitian ini diharapkan dapat mengembangkan ilmu pengetahuan yang diperoleh dalam perkuliahan dan membandingkannya dengan praktek di lapangan, khususnya ilmu pengetahuan di bidang Hukum Lingkungan.

b) Penelitian ini sebagai sarana untuk mengetahui secara mendalam mengenai beberapa kebjakan tentang pengelolaan limbah dan kebijakan tentang rumah sakit.

\section{b. Manfaat Praktis}

a) Penelitian ini diharapkan dapat memberi informasi tentang kebijakan dan prosedur pengelolaan Rumah Sakit Islam Sultan Agung Kota Semarang.

b) Memberikan sumbangan pemikiran di bidang ilmu hukum pada umumnya dan pada khususnya tentang proses pengelolaan limbah rumah sakit.

\section{Tinjauan Pustaka}

\section{Pengertian Implementasi Kebijakan}

Implementasi berasal dari bahasa Inggris yaitu to implement yang berarti mengimplementasikan. Kebijakan sendiri dapat didefinisikan sebagai suatu ucapan atau tulisan yang memberikan petunjuk umum tentang penetapan ruang lingkup yang memberi batas dan arah umum kepada seseorang untuk bergerak. Dari pengertian di atas maka dapat disimpulkan bahwa, definisi implementasi kebijakan yaitu suatu tindakan yang dilakukan oleh individu / pejabat atau kelompok pemerintah atau swasta yang diarahkan pada tercapainya tujuan yang telah digariskan dalam keputusan yang mempunyai tujuan yang dilakukan secara tertib dan berisikan ketentuan - ketentuan yang dapat dijadikan pedoman guna mewujudkan sasaran yang diinginkan.

\section{Kajian Tentang Perlindungan dan Pengelolaan Lingkungan}

Menurut Pasal 1 UU Nomor 32 Tahun 2009 tentang Perlindungan dan Pengelolaan Lingkungan Hidup, Lingkungan hidup adalah kesatuan ruang dengan semua benda, daya, 
keadaan, dan makhluk hidup, termasuk manusia dan perilakunya, yang mempengaruhi alam itu sendiri, kelangsungan perikehidupan, dan kesejahteraan manusia serta makhluk hidup lain. Kesehatan lingkungan merupakan hak asasi manusia dan salah satu unsur kesejahteraan yang harus diwujudkan sesuai dengan cita - cita bangsa Indonesia sebagaimana dimaksud dalam Pancasila dan UUD RI $1945 .^{3}$ Hukum Pengendalian pencemaran lingkungan, antara lain meliputi ketentuan hukum tentang pencegahan dan penanggulangan pencemaran lingkungan. Berdasarkan Pasal 20 ayat (1) UU Nomor 32 Tahun 2009 tentang Perlindungan dan Pengelolaan Lingkungan Hidup, penentu terjadinya pencemaran lingkungan hidup diukur melalui baku mutu lingkungan hidup. Kemudian sesuai dengan Pasal 2 PP Nomor 27 Tahun 2012 tentang Izin Lingkungan menyebutkan bahwa Setiap Usaha dan/atau Kegiatan yang wajib memiliki Amdal atau UKL-UPL wajib memiliki Izin Lingkungan. Bertitik tolak pada Pasal 40 ayat (1) PP Nomor 82 Tahun 2001 tentang Pengelolaan Kualitas Air dan Pengendalian Pencemaran Air, menyatakan bahwa setiap usaha atau kegiatan yang akan membuang air limbah ke air atau sumber air wajib mendapatkan izin tertulis dari Bupati/Walikota. Menurut Pasal 38 PP Nomor 82 Tahun 2001, setiap penanggung jawab usaha atau kegiatan yang membuang air limbah ke air atau sumber air wajib mentaati persyaratan yang ditetapkan dalam izin.

\section{Kajian Tentang Limbah Rumah Sakit}

\section{a. Pengertian Limbah Rumah Sakit}

Limbah rumah sakit adalah semua limbah yang dihasilkan dari kegiatan Rumah Sakit dalam bentuk padat, cair, pasta (gel) maupun gas yang dapat mengandung mikroorganisme pathogen bersifat infeksius, bahan kimia beracun, dan sebagian bersifat radioaktif. Limbah rumah sakit cenderung bersifat infeksius dan kimia beracun yang dapat mempengaruhi kesehatan manusia, memperburuk kelestarian lingkungan hidup apabila tidak dikelola dengan baik. ${ }^{4}$

\section{b. Macam - macam Limbah Rumah Sakit}

Pada dasarnya jenis dan sumber sampah di rumah sakit dapat diklasifikasikan menjadi 2 yaitu limbah non medis dan limbah medis. Limbah non medis dapat berasal dari sampah perkantoran, sampah di unit - unit pelayanan, sisa - sisa pembuangan di dapur, sampah di ruangan pasien dan ruang tunggu pasien dll. Sedangkan sampah medis atau disebut juga dengan limbah medis dapat dikelompokan sebagai berikut : Limbah benda

\footnotetext{
${ }^{3}$ Masrudi Muchtar, Dkk, Hukum Kesehatan Lingkungan (Yogyakarta : Pustaka Baru Press, 2016), halaman17.

${ }^{4}$ Humas RSHS, Limbah Rumah Sakit (Online), http://web.rshs.or.id/limbah-rumah-sakit/. Diakses pada tanggal 5 November 2017, pukul 18:56 WIB.
} 
tajam, limbah infeksius, limbah jaringan tubuh, limbah sitotoksik, limbah farmasi, limbah kimia, limbah radio aktif, limbah plastik. ${ }^{5}$

\section{c. Pengelolaan Limbah Rumah Sakit}

Guna meningkatkan mutu lingkungan dan sanitasi di rumah sakit maka perlu dibuatnya Instalansi Pengolah Air Limbah (IPAL) yang baik dan teruji prosesnya. Sementara itu, tujuan sanitasi lingkungan rumah sakit adalah tercapainya kondisi lingkungan rumah sakit yang memenuhi persyaratan sanitasi, yang menjamin pencegahan penyakit akibat pemaparan oleh bahaya - bahaya lingkungan rumah sakit termasuk infeksi nosokomial, membantu proses pengobatan dan penyembuhan penderita dan pencegahan pencemaran lingkungan sekitar rumah sakit. ${ }^{6}$

\section{Penegakan Hukum Lingkungan}

Penegakan hukum pada prinsipnya dapat dilakukan melalui upaya yang sifatnya preventif dan represif. Pada hakekatnya penegakan hukum dalam konteks perlindungan dan pengelolaan lingkungan hidup bertujuan untuk mencegah penyusutan dan kemerosotan mutu lingkungan. Penegakan hukum dalam UU Nomor 32 Tahun 2009 tentang Perlindungan Dan Pengelolaan Lingkungan Hidup dapat diklasifikasikan ke dalam 3 (tiga) kategori yaitu : hukum administrasi, hukum perdata dan hukum pidana. ${ }^{7}$ Berdasarkan hal pencemaran lingkungan hidup, pemerintah dengan tegas memberikan sanksi - sanksi terhadap pelaku yang dituangkan dalam kebijakan dari sanksi administrasi hingga sanksi pidana.

\section{E. METODE PENELITIAN}

\section{Jenis / Tipe Penelitian}

Jenis / tipe penelitian ini yang penulis gunakan adalah jenis / tipe penelitian yuridis sosiologis yang dilakukan secara langsung dengan melihat kenyataan yang ada dalam praktek dilapangan. ${ }^{8} \quad$ Jenis / tipe penelitian secara yuridis sosiologis sangatlah penting karena untuk mengetahui seberapa jauh implementasi kebijakan itu diterapkan di masyarakat dan dalam suatu kegiatan pengelolaan limbah di Rumah Sakit Islam Sultan Agung.

\section{Spesifikasi Penelitian}

Spesifikasi yang dipergunakan dalam penelitian ini adalah deskriptif analitis, yaitu penelitian yang berusaha mendeskripsikan suatu gejala, peristiwa, kejadian yang terjadi saat

\footnotetext{
5 Lim Mulyono, Limbah Rumah Sakit (Online), https://kantongampah123.com/2016/02/04/limbah-rumah-sakit/. Diakses pada tanggal 15 November 2017, pukul 09:57 WIB

${ }^{6}$ Wiku Adisasmito, Audit Lingkungan Rumah Sakit (Jakarta:PT. RajaGrafindo Persada, 2008), halaman 34

${ }^{7}$ Masrudi Muchtar, dkk, Op.cit, halaman 112-113.

${ }^{8}$ III METODE PENEITIAN (Online), http://digilib.unila.ac.id/525/8/BAB\%20III.pdf. Diakses pada tanggal 23 April 2017, pukul : 0.27 WIB
} 
sekarang. Dalam penelitian ini, penulis akan mendeskripsikan tentang implementasi pengelolaan limbah di Rumah Sakit Sultan Agung sesuai dengan kebijakan yang berlaku saat ini seperti UU Nomor 32 Tahun 2009 tentang Perlindungan dan Pengelolaan Lingkungan Hidup, UU Nomor 44 Tahun 2009 tentang Rumah Sakit dan Keputusan Menteri Kesehatan Republik Indonesia Nomor 1204/MENKES/SK/X/2004 tentang Persyaratan Kesehatan Lingkungan Rumah Sakit.

\section{Metode Penentuan Sampel}

Penelitian ini menggunakan cara pengambilan sampel sistematis Non Random yang dilakukan dengan cara teknik Purposive Sampling. Metode penentuan sampel secara purposive sampling karena pengambilan sampel ini dengan cara menentukan kriteria sampel terlebih dahulu. Pengambilan sampel ini dengan cara turun langsung ke lapangan dan menuju langsung ke tempat yang ingin diteliti.

\section{Metode Pengumpulan Data}

Penelitian ini menggunakan data primer karena sumber data yang diperoleh berupa data yang didapat langsung dari lapangan. Data primer ini diperoleh melalui cara wawancara terhadap pihak terkait secara langsung dan pengamatan di lapangan serta didukung data sekunder.

\section{Metode Analisis data}

Metode analisis data yang dipergunakan dalam penelitian ini adalah analisis kualitatif. Penelitian ini dibuat dengan melalui proses pengumpulan dan memilah - milah data dari lapangan. Pengumpulan data dalam penelitian kualitatif tidak bersifat kaku tetapi selalu disesuaikan dengan keadaan dilapangan. ${ }^{9}$

\section{F. HASIL PENELITIAN DAN PEMBAHASAN}

\section{Jenis Limbah Rumah Sakit Islam Sultan Agung Kota Semarang}

\section{a. Limbah Medis}

Menurut sifatnya, limbah medis dibagi menjadi 3 (tiga) yaitu limbah padat, limbah cair, dan limbah gas.

a. Limbah medis padat

Limbah medis padat sendiri memiliki pengertian semua sisa atau bekas pengelolaan pasien yang terkena cairan tubuh dari pasien baik berupa sekresi maupun ekskresi yang dihasilkan dari ruang keperawatan, labotarium, kamar bedah, IGD. Contoh limbah medis padat yang dihasilkan Rumah Sakit Islam Sultan Agung seperti 
HUMANI (Hukum dan Masyarakat Madani) P-ISSN: 1411-3066

${ }^{9}$ Ibid, halaman 169
Volume 7 No. 3 Desember 2017 Halaman 223-236

E-ISSN: 2580-8516 
perban atau pembungkus yang kotor, cairan badan, anggota badan yang diamputasi, jarum-jarum dan semprit bekas, kantong urin dan produk darah, botol infus, ampul, botol bekas injeksi, kateter, plester, dan masker.

b. Limbah cair

Limbah cair di Rumah Sakit Islam Sultan Agung berupa semua air buangan termasuk tinja yang berasal dari kegiatan rumah sakit yang kemungkinan mengandung mikro organisme dan bahan kimia beracun. Contohnya seperti air cuci alat, air cuci tangan pasien, air bekas mandi atau siben, spesimen dari laboratorium berupa Sampel yang diambil daripada pesakit, paling biasanya darah, kencing, atau mani dan sebagainya.

c. Limbah gas

Limbah medis gas yang dihasilkan oleh Rumah Sakit Islam Sultan Agung adalah semua limbah yang berbentuk gas yang berasal dari kegiatan pembakaran di rumah sakit seperti insinerator, dapur, perlengkapan generator (genset), anastesi, dan pembuatan obat citotoksik. Limbah gas yang menghasilkan sumber emisi dibedakan menjadi 2 yaitu sumber emisi bergerak dan tidak bergerak. Untuk mengimplementasikan PP Nomor 41 Tahun 1999 tentang Pengendalian Pencemaran Udara khususnya Pasal 16, sehingga Rumah Sakit Sultan Agung melakukan pemerikasaan, pengawasan, pengujian dan pengkajian terhadap sumber emisi bergerak dan tidak bergerak dalam kurun waktu 1 tahun sekali. Pemerikasaan, pengawasan, pengujian dan pengkajiannya Rumah Sakit Sultan Agung menggunakan jasa laboratorium swasta sepeti PT. Superintending Company of Indonesia (SUCOFINDO) atau PT. Cito Diagnostika Utama.

\section{b. Limbah Non Medis}

Limbah non medis yang dihasilkan oleh Rumah Sakit Sultan Agung dibagi menjadi dua yaitu limbah padat, limbah cair.

a) Limbah padat

Limbah non medis menurut sifatnya juga memiliki limbah padat. Limbah non medis yang bersifat padat adalah semua sampah organik dan anorganik yang dihasilkan oleh Rumah Sakit Sultan Agung yang tidak mengandung cairan tubuh pasien.

b) Limbah cair 
Limbah cair rumah sakit umumnya mengandung senyawa polutan organik yang cukup tinggi dan dapat diolah dengan proses pengelolaan secara biologis. ${ }^{10}$ Sementara itu, untuk limbah cair non medis yang berasal dari semua air sisa pembuangan dari Air Conditioner (AC) dan air hujan tersebut tidak berbaya terhadap lingkungan hidup sehingga tidak ada penanganan secara khusus. Dalam pembungannya, limbah cair non medis tersebut hanya diberi saluran pembuangan yang menuju langsung ke badan air.

\section{Pengelolaan Limbah Rumah Sakit Islam Sultan Agung Kota Semarang}

\section{a. Limbah Medis Padat}

Menurut Kepmenkes RI Nomor 1204/MENKES/SK/X/2004 tentang Persyaratan Kesehatan Rumah Sakit, persyaratan dalam pengelolaan limbah rumah sakit haruslah memenuhi tahapan seperti minimasi limbah, pemilahan, pewadahan, pemanfaatan kembali dan daur ulang. Proses pemilahan limbah medis berawal dari perawat dan petugas kebersihan pada tahap pengangkutan. Dari hasil wawancara, Ibu Emy Yuni Astuti menyatakan bahwa dalam hal sarana dan prasarana pengelolaan limbah medis padat, Rumah Sakit Islam Sultan Agung menyediakan sarana pengelolaan limbah medis padat dimulai dari wadah pemilahan limbah, troli untuk pengangkutan limbah medis padat dari ruangan penghasil limbah ke tempat penampungan sementara B3 (bak penampung). ${ }^{11}$ Untuk pengelolaan limbah medis padat sendiri, Rumah Sakit Islam Sultan Agung menggunakan jasa pihak ketiga yaitu perusahaan transporter. Kegiatan perusahaan transporter di Rumah Sakit Islam Sultan Agung berdasarkan atas M.O.U (Memorandum Of Understanding) yaitu dimulai dari pembersihan, pengangkutan, pengumpulan serta pengelolaan dilakukan sesuai dengan Peraturan Pemerintah Nomor 74 Tahun 2001 tentang Pengelolaan Bahan Berbahaya Dan Beracun. Berdasarkan pada Pasal 31 Peraturan Pemerintah Nomor 74 Tahun 2001 tentang Pengelolaan Bahan Berbahaya Dan Beracun yang berbunyi : "Setiap orang yang melakukan kegiatan pengelolaan B3 wajib menyampaikan laporan tertulis tentang pengelolaan B3 secara berkala sekurangkurangnya setiap 6 (enam) bulan kepada instansi yang bertanggung jawab dan instansi yang berwenang di bidang tugas masing-masing dengan tembusan kepada Gubernur/Bupati/ Walikota", oleh karena itu setiap satu bulan sekali Rumah Sakit Islam Sultan Agung diberi lembar Manifesh oleh perusahaan transporter.

\footnotetext{
${ }^{10}$ Wiku Adisasmto, Sistem manajemen Lingkungan Rumah Sakit (Jakarta:Rajawali Pers, Cetakan ke-3, 2014), halaman 144.

${ }^{11}$ Astuti, Emy Yuni. Kepala Bagian Sanitasi dan Loundry. Wawancara. Semarang 19 November 2017
} 


\section{b. Limbah Padat Non Medis}

Menurut Pasal 4 Peraturan Daerah Kota Semarang Nomor 6 Tahun 2012 tentang Pengelolaan Sampah menyebutkan bahwa "Pengelolaan sampah bertujuan untuk meningkatkan kesehatan masyarakat dan kualitas lingkungan serta menjadikan sampah sebagai sumber daya." Sehingga untuk sampah organik sendiri Rumah Sakit Islam Sultan Agung mengelolanya menjadi kompos. Sedangkan untuk sampah anorganiknya Rumah Sakit Islam Sultan Agung bekerja sama dengan Dinas Lingkungan Hidup Kota Semarang dari pengangkutan hingga pengolahannya. Rumah Sakit Islam Sultan Agung setiap bulannya dikenakan biaya retribusi untuk biaya pelayanan persampahan / kebersihan sesuai dengan PERDA Kota Semarang Nomor 2 Tahun 2012 tentang Reribusi Jasa Umum Di Kota Semarang, khususnya pada Pasal 10 ayat (1) huruf b angka 2.

\section{c. Limbah Cair Medis dan Non Medis}

Limbah medis cair yang dihasilkan dari sebuah rumah sakit pada umumnya mengandung banyak bakteri, virus, senyawa kimia, dan obat - obatan yang dapat membayakan bagi kesehatan masyarakat sekitar rumah sakit. ${ }^{12}$ Guna meningkatkan mutu lingkungan sekitar dan sanitasi di Rumah Sakit Islam Sultan Agung maka pengelolaan limbah cair di Rumah Sakit Islam Sultan Agung menggunakan IPAL (Instalasi Pengelolaan Air Limbah) dengan proses pengelolaan biofilter anaerob - aerob. Dengan sistem kombinasi biofilter anaerob - aerob akan diperoleh hasil air olahan yang baik, serta pengolahannya sangat stabil walaupun konsentrasi maupun debit air limbah berfluktuasi. ${ }^{13}$ Semua limbah cair yang dihasilkan Rumah Sakit Islam Sultan Agung ditampung di bak penampungan. Setiap gedung Rumah Sakit Islam Sultan Agung memiliki bak penampungan air limbah. Dalam hal pengelolaan limbah cair, Rumah Sakit Islam Sultan Agung tidak ada pemisahan antara limbah cair infeksius maupun non infeksius. Akan tetapi untuk limbah hasil labotarium dipisahkan dan ditampung terlebih dahulu untuk diolah secara kimia - fisika kemudian dialirkan ke bak penampungan / bak equalisasi bersama dengan limbah cair yang lain. Proses biofilter yaitu proses pengelolaan limbah di mana menggunakan bantuan bakteri guna mengurai senyawa polutan. Limbah cair yang telah ditampung dalam bak Equalisasi / bak sedimentasi kemudian dipompa kembali ke mesin reaktor biofilter. Setelah melalui proses penyaringan 3 (tiga) tahap, air limbah tersebut dialirkan ke bak pengujian biologis setelah itu dialirkan ke bak desinfektan. Setelah limbah cair berada di bak desinfektan, limbah cair tersebut siap untuk dibuang ke badan air. Kualitas air limbah hasil olahan IPAL Rumah Sakit Islam Sultan Agung yang akan dibuang ke badan air harus memenuhi persyaratan baku mutu

\footnotetext{
${ }^{12}$ Asmadi, Pengelolaan Limbah Medis Rumah Sakit (Yogjakarta:Gosyen Publishing, Cetakan Pertama, halaman 83.

${ }^{13}$ Ibid., halaman 87.
} 
sesuai dengan Keputusan Menteri Lingkungan Hidup Nomor Kep-58/MenLH/12/1995. Pada pengecekan baku mutu limbah cair, Rumah Sakit Islam Sultan Agung menggunakan jasa pengujian Labotarium Dinas Lingkungan Hidup Kota Semarang pada tiap bulannya dan hasil akan diterima 2 minggu setelah pengujian Labotarium dilakukan.

3. Kendala yang dihadapi oleh Rumah Sakit Islam Sultan Agung Kota Semarang dalam mengimplementasikan kebijakan pengelolaan limbah rumah sakit

Pada umumnya setiap pelayanan kesehatan diseluruh Indonesia pasti akan mempunyai suatu kendala dalam pengelolaan limbah. Begitu juga dengan Rumah Sakit Islam Sultan Agung Kota Semarang. Dalam PERDA Provinsi Jawa Tengah Nomor 5 Tahun 2012 tentang Perubahan Atas Peraturan Daerah Provinsi Jawa Tengah Nomor 10 Tahun 2004 tentang Baku Mutu Air Limbah khususnya pada lampiran ke IV tentang baku mutu air limbah untuk kegiatan rumah sakit, terdapat standarisasi tentang NH3-N Bebas yang menyatakan maksimal 0,1 mg/L. Menurut pernyataan Ibu Emy, di tahun 2016 Rumah Sakit Islam Sultan Agung menghadapi sebuah kendala berupa standarisasi baku mutu NH3-N Bebas (Amonia) yang mencapai 1,6 mg/L.

4. Upaya mengatasi kendala yang dihadapi oleh Rumah Sakit Islam Sultan Agung Kota Semarang dalam mengimplementasikan kebijakan pengelolaan limbah rumah sakit

Upaya yang dilakukan oleh Rumah Sakit Islam Sultan Agung dan pelayanan kesehatan seluruh Jawa Tengah dalam mengimplementasikan kebijakan PERDA Provinsi Jawa Tengah Nomor 5 Tahun 2012 tentang Perubahan Atas Peraturan Daerah Provinsi Jawa Tengah Nomor 10 Tahun 2004 tentang Baku Mutu Air Limbah khususnya pada lampiran ke IV tentang baku mutu air limbah untuk kegiatan rumah sakit yang mengatur standarisasi NH3-N Bebas yang menyatakan maksimal 0,1 mg/L yaitu mengadakan pertemuan Forum Kelompok Sanitarian Kota Semarang yang dihadiri pembicara dari Kementrian Republik Indonesia. Dari upaya yang ditempuh maka Rumah Sakit Islam Sultan Agung mendapatkan solusi atas kendala yang dihadapi berupa Kementrian Republik Indonesia membuat kebijakan baru yaitu Peraturan Menteri Lingkungan Hidup Dan Kehutanan Republik Indonesia Nomor: P.68/Menlhk/Setjen/Kum.1/8/2016 tentang Baku Mutu Air Limbah Domestik dengan standarisasi NH3-N Bebas / Amonia sebesar 10 $\mathrm{mg} / \mathrm{L}$. 


\section{G. Penutup}

\section{a. Simpulan}

Implementasi kebijakan pengelolaan limbah rumah sakit di Rumah Sakit Islam Sultan Agung Kota Semarang secara umum sudah berjalan dengan baik. Walaupun secara umum pelaksanaan kebijakan pengelolaan limbah rumah sakit di Rumah Sakit Islam Sultan Agung sudah baik, namun menurut data yang diterima oleh penulis masih ada kendala yang dihadapi oleh Rumah Sakit Islam Sultan Agung yaitu mengenai standar baku mutu amonia yang ditetapkan oleh Pemerintah Provinsi Jawa Tengah pada tahun 2016. Berdasarkan kendala yang ada, secara kompleks kendala yang dihadapi oleh Rumah Sakit Islam Sultan Agung juga dihadapi oleh beberapa pelayanan kesehatan di Kota Semarang. Oleh karena itu, Rumah Sakit Islam Sultan Agung dan beberapa pelayanan kesehatan Kota Semarang melakukan upaya pertemuan Forum Kelompok Sanitarian Kota Semarang yang dihadiri pembicara dari Kementrian Republik Indonesia guna membahas kendala yang ada. Dengan adanya pembahasan ini Kementrian Republik Indonesia mengeluarkan kebijakan baru berupa Peraturan Menteri Lingkungan Hidup Dan Kehutanan Republik Indonesia Nomor P.68/Menlhk/Setjen/Kum.1/8/2016 tentang Baku Mutu Air Limbah Domestik dengan standarisasi NH3-N Bebas / Amonia sebesar $10 \mathrm{mg} / \mathrm{L}$ guna menangani kendala yang dihadapi oleh Rumah Sakit Islam Sultan Agung dan beberapa pelayanan kesehatan Kota Semarang.

\section{b. Saran}

Diharapkan Rumah Sakit Islam Sultan Agung tidak hanya mengelola limbah padat non medis organik saja akan tetapi juga dapat mengelola limbah padat non medis anorganik menjadi barang yang bermanfaat dan memiliki nilai jual sehingga dapat meminimalis pembayaran retribusi dan mengurangi penumpukan sampah di TPA Jati Barang.

\section{DAFTAR PUSTAKA}

\section{Buku - buku :}

Adisasmito, Wiku, Audit Lingkungan Rumah Sakit. Jakarta:PT. RajaGrafindo Persada, 2008 -Sistem manajemen Lingkungan Rumah Sakit. Jakarta:Rajawali Pers, Cetakan ke-3, 2014.

Asmadi, Pengelolaan Limbah Medis Rumah Sakit. Yogjakarta:Gosyen Publishing, Cetakan Pertama, 2013.

Astuti, Emy Yuni. Wawancara tentang Pengelolaan Limbah Rumah Sakit Islam Sultan Agung Kota Semarang. Semarang : Bagian Sanitasi dan Laundry, 2017

Erwin, Muhamad, Hukum Lingkungan : Dalam Sistem Kebijaksanaan Pembangunan Lingkungan Hidup. Bandung : PT. Refika Aditama, 2008. 
Masrudi Muchtar, Abdul Khair dan Noraida, Hukum Kesehatan Lingkungan. Yogyakarta : Pustaka Baru Press, 2016.

\section{Peraturan Perundang - undangan:}

Seketariat Negara RI. Undang - Undang Nomor 32 Tahun 2009 Tentang Perlindungan dan Pengelolaan Lingkungan Hidup. Jakarta, 2009.

Seketariat Negara RI. Peraturan Menteri Lingkungan Hidup Dan Kehutanan Republik Indonesia Nomor P.68/Menlhk/Setjen/Kum.1/8/2016 Tentang Baku Mutu Air Limbah Domestik. Jakarta, 2016.

\section{Website :}

III METODE PENEITIAN (online), http://digilib.unila.ac.id/525/8/BAB\%20III.pdf, diakses 23 April 2017.

Mulyono, Lim, Limbah Rumah Sakit (online), https://kantongampah123.com/2016/02/04/limbah-rumah-sakit/, diakses 15 November 2017

Humas RSHS, Limbah Rumah Sakit (online), http://web.rshs.or.id/limbah-rumah-sakit/, diakses 5 November 2017.

BAB III Rumah Sakit Islam Sultan Agung Semarang Dan Pelaksanaan Bimbingan Rohani Islam (online), http://eprints.walisongo.ac.id/7121/4/BAB\%20III.pdf,diakses pada tanggal 21 November 2017. 